\title{
The Synthesis and Characterization of Poly(methyl methacrylate-tourmaline acrylate)
}

\author{
Yingmo Hu, Xubo Chen, and Yunhua Li \\ Beijing Key Laboratory of Materials Utilization of Nonmetallic Minerals and Solid Wastes, National Laboratory of Mineral Materials, \\ School of Materials Science and Technology, China University of Geosciences, Beijing 100083, China
}

Correspondence should be addressed to Yingmo Hu; huyingmo@cugb.edu.cn

Received 2 June 2015; Revised 24 February 2016; Accepted 25 February 2016

Academic Editor: Jainagesh A. Sekhar

Copyright (C) 2016 Yingmo Hu et al. This is an open access article distributed under the Creative Commons Attribution License, which permits unrestricted use, distribution, and reproduction in any medium, provided the original work is properly cited.

In order to synthesize the tourmaline-containing functional copolymer, the polymerizable organic tourmaline acrylate was prepared by the surface modification on tourmaline powder and then copolymerization with methyl methacrylate to get poly(methyl methacrylate-tourmaline acrylate). The synthetic processes were optimized, and the structures of the as-prepared samples were characterized by IR, SEM, and X-ray fluorescence analysis. The characterization results indicated that the tourmaline has been introduced into the copolymer by means of surface modification with acryloyl chloride and following copolymerization with methyl methacrylate. The results from the negative ions measurement revealed that the amounts of released negative ions from both the modified tourmaline and its copolymer are much larger than that of tourmaline.

\section{Introduction}

Tourmaline is one of the typical cyclosilicate minerals; the general chemical formula of the tourmaline group can be expressed as $(\mathrm{Na}, \mathrm{Ca})\left(\mathrm{Mg}, \mathrm{Fe}, \mathrm{Mn}, \mathrm{Li}, \mathrm{Al}_{3}\right)_{3} \mathrm{Al}_{6}\left(\mathrm{Si}_{6} \mathrm{O}_{18}\right)\left(\mathrm{BO}_{3}\right)_{3}$ $(\mathrm{OH}, \mathrm{F})_{4}$ and divided into schorl, dravite, and elbaite depending on different isomorphism states [1]. The complex crystal structures of tourmaline lead to the specific functional characteristics, such as permanently spontaneous polarization [2], thermoelectricity [3], piezoelectricity [4], far-infrared radiation [5], and negative ion releasing [6]. Tourmaline has been paid broad attention as a novel functional mineral material with lots of potential merits. Many researchers have done much work to explore the functional tourmaline composites and their applications.

Tourmaline/titanium dioxide/nylon-6 composite materials show good photocatalytic properties on photodegradation of organic pollutant and have potential application in water treatment $[7,8]$, and tourmaline/zinc composites have also been applied as catalytic materials in heat exchangers for mitigation of calcium carbonate $\left(\mathrm{CaCO}_{3}\right)$ fouling or scaling by physical water treatment [9]. Wu et al. [10] used the hydroxyl silicone-oil to modify tourmaline and then composited it with polyurethane to get superhydrophobic film materials that can release negative air ions. The surface organic modification on tourmaline powder with span-60 was studied [11]; the modified tourmaline powder approached $100 \%$ activation index and showed an excellent hydrophobicity and then composited with polypropylene to get well-dispersed tourmaline/PP composite. The amounts of released negative ions over both modified tourmaline and its composite were greater than that of unmodified tourmaline. Tijing et al. [12] have fabricated tourmaline/polyurethane hybrid mat by electrospinning the homogeneous dispersion of superhydrophilic tourmaline in polyurethane and showed that it possesses high antibacterial activity against Escherichia coli and enterococci bacteria. Zheng and Wang [13] applied polyvinyl alcohol semi-IPN poly (acrylic acid)/tourmaline composite to remove heavy metals in waste water.

In order to synthesize the tourmaline-containing functional polymer, the surface modification on tourmaline powder with acryloyl chloride was made in this work to synthesize the polymerizable tourmaline acrylate, and then it was copolymerized with methyl methacrylate to get the tourmaline-containing copolymer. The preparation process was investigated in detail by optimizing the experimental parameters of contact angles and turbidities of modified tourmaline. The structures were characterized by IR, 
SEM, and X-ray fluorescence analysis, and the amounts of released negative ions on both modified tourmaline and its copolymer have been measured quantificationally.

\section{Experimental and Materials}

2.1. Materials. Tourmaline powder (TM, $d_{50}=1.75 \mu \mathrm{m}$, $\left.d_{97}=5.23 \mu \mathrm{m}\right)$ was obtained from Yanxin Mineral Co. Ltd., Hebei, China; N,N-dimethylformamide (DMF, CP, Xilong Chemical Co., Ltd., Shantou, China) was dehydrated by anhydrous sodium sulfate; methyl methacrylate (CP, Tianjin Fuchen Chemical Reagents Factory, China) was newly distilled before being used; acryloyl chloride (CP, Huateng Technology Co., Ltd., Beijing, China), sulfuric acid (CP, Beijing Chemical Works, Beijing, China), anhydrous alcohol (CP, Beijing Chemical Works, Beijing, China), and liquid paraffin (CP, Tianjin Fuchen Chemical Works, Tianjin, China) were used as original.

2.2. The Preparation of Tourmaline Acrylate. In a $100 \mathrm{~mL}$ four-neck flask equipped with condenser, funnel, thermometer, and electromagnetic stirrer, 5 grams of tourmaline powder was dispersed in $15 \mathrm{~mL}$ dried DMF and heated to $40^{\circ} \mathrm{C}$ with sufficient stirring. $0.1 \mathrm{~mL}$ of sulfuric acid was added to a flask, and $3.0 \mathrm{~mL}$ acryloyl chloride was dropped into the flask with funnel. Then, the mixture was stirred for $3 \mathrm{~h}$ at $40^{\circ} \mathrm{C}$. The samples were separated by filtration with vacuum and washed for three times with anhydrous ethanol and finally dried to get the tourmaline acrylate.

2.3. The Synthesis of Poly(methyl methacrylate-tourmaline acrylate). Anhydrous dimethylformamide (DMF, $70 \mathrm{~mL}$ ) was poured into a $250 \mathrm{~mL}$ four-neck flask with condenser, funnel, thermometer, and electromagnetic stirrer, then nitrogen was added into DMF for $30 \mathrm{~min}$, and then the flask was heated to $80^{\circ} \mathrm{C}$. The $50 \mathrm{~mL}$ of newly distilled methyl methacrylate (MMA) solution $0.2 \mathrm{~g}$ benzoperoxide (BPO) was added dropwise. And tourmaline acrylate was added into the flask when the viscosity of reaction system began to increase and continued reacting for $8 \mathrm{hr}$ at $80^{\circ} \mathrm{C}$ to get poly(methyl methacrylate-tourmaline acrylate) copolymer solution, and the tourmaline-containing fibers were prepared via electrospinning.

2.4. The Determination of Turbidity. 1.0 gram of modified tourmaline powder was added into a $100 \mathrm{~mL}$ beaker with $50 \mathrm{~mL}$ liquid paraffin. The mixture was stirred for $5 \mathrm{~min}$ and allowed to stand for $24 \mathrm{~h}$. Then, the supernatant liquid was collected and its turbidity was tested by SGZ-2 nephelometer.

2.5. The Measurement of Contact Angle. The sample was pressed into a circle using the presser, and then the distilled water was dropped onto the surface of the sample to evaluate the contact angle with DSA100M optical instruments; each value was averaged over three tests.

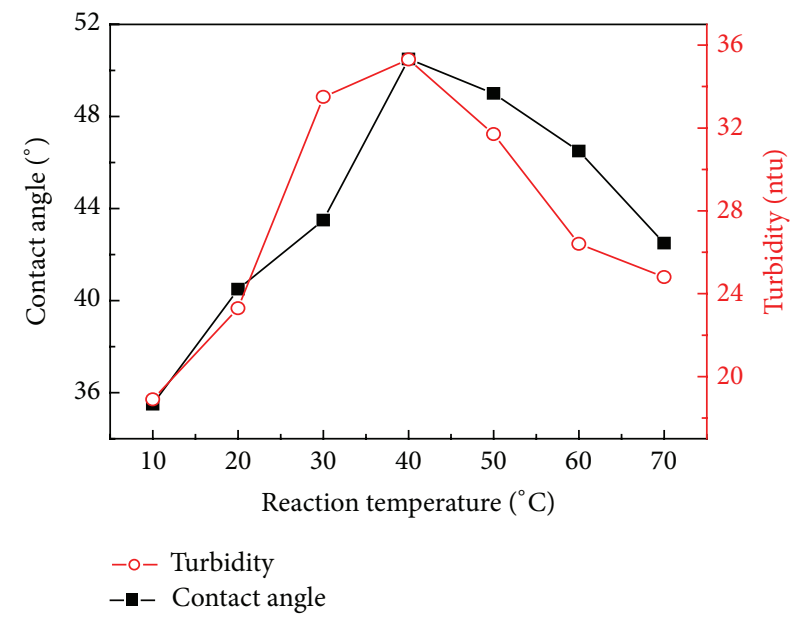

FIGURE 1: Effect of reaction temperature.

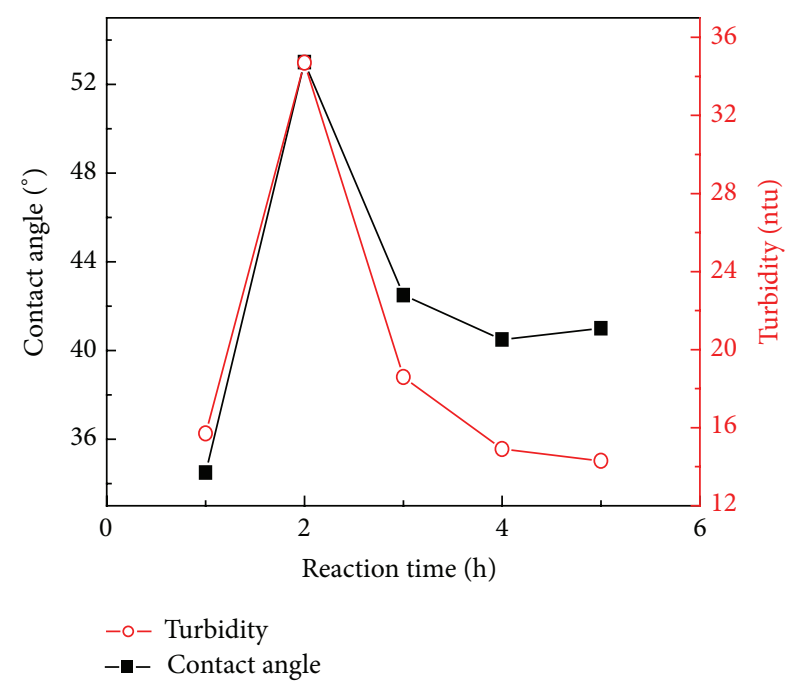

FIGURE 2: Effect of reaction time.

\section{Results and Discussion}

3.1. The Optimization of Acryloyl Chloride Modified Tourmaline. The modified effects of tourmaline powder with acryloyl chloride under various experimental conditions were studied by focusing on the experimental parameters of turbidity in liquid paraffin and contact angles of product.

3.1.1. Effect of the Reaction Temperature. The curves of contact angle and turbidity of modified tourmaline at different reaction temperature were shown in Figure 1. Both contact angle and turbidity of modified tourmaline increased with rising of the reaction temperature below $40^{\circ} \mathrm{C}$ and then reduced with the persistent rising of reaction temperature, reaching the maximum at $40^{\circ} \mathrm{C}$.

3.1.2. Effect of Reaction Time. Figure 2 revealed the influence of reaction time on the contact angle and turbidity of modified tourmaline. Figure 2 showed the same trend for 


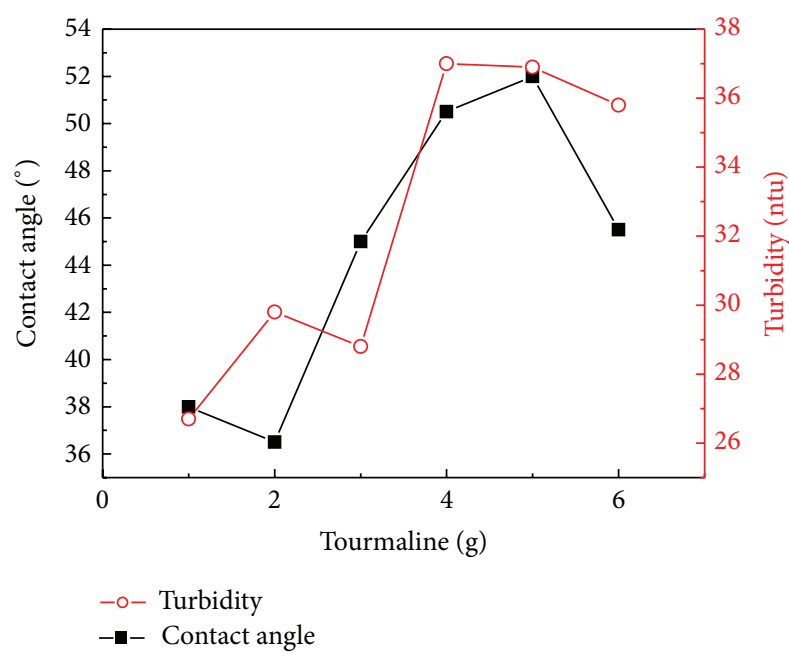

FIgURE 3: Effect of the amount of tourmaline.

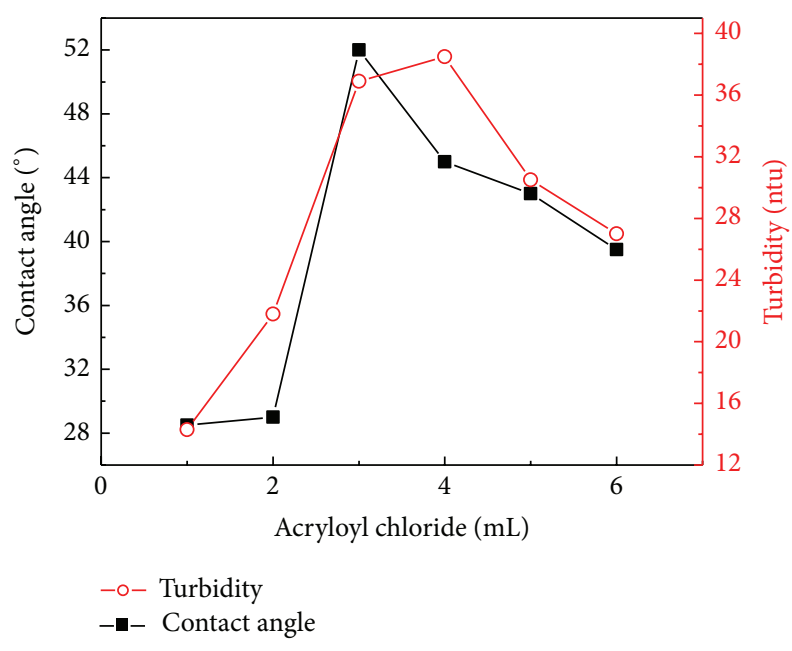

FIGURE 4: Effect of acryloyl chloride.

contact angle and turbidity of modified tourmaline, which increased sharply at first and then decreased with prolonging the reaction time. The optimal reaction time was $2 \mathrm{~h}$.

3.1.3. Effect of the Dosage of Tourmaline. By fixing the dosage of solvent (DMF) as $50 \mathrm{~mL}$, the effect of the amount of tourmaline on the contact angle and turbidity of modified tourmaline were shown in Figure 3. The contact angle and turbidity of modified tourmaline tended to increase with the increase of tourmaline and then decrease when the amount of tourmaline was over $5 \mathrm{~g}$. Accordingly, the optimal amount of tourmaline was $5 \mathrm{~g}$ in this work.

3.1.4. Effect of Acryloyl Chloride. The effect of acryloyl chloride on turbidity and contact angle of modified tourmaline was exhibited in Figure 4. The turbidity and contact angle of modified tourmaline increased speedily with the increase of acryloyl chloride amount at the beginning and then reduced with further increasing acryloyl chloride when the dosage

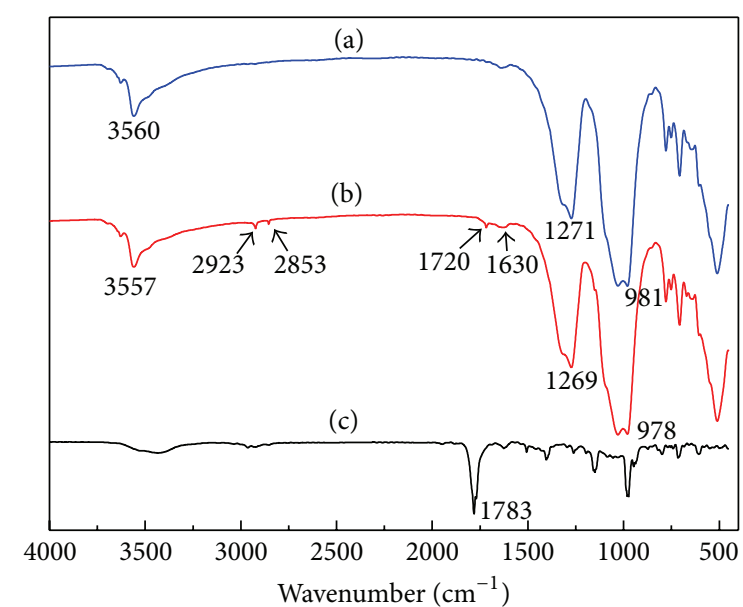

FIGURE 5: FT-IR spectra of tourmaline (a), modified tourmaline (b), and acryloyl chloride (c).

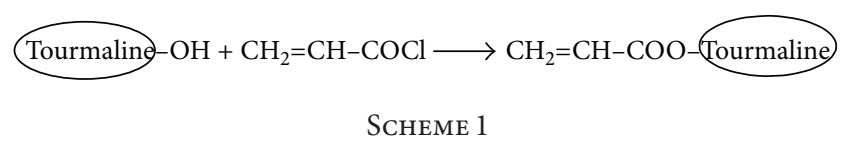

of acryloyl chloride was over $3 \mathrm{~mL}$, which is the optimum amount of acryloyl chloride.

\subsection{Structural Characterization of Tourmaline Acrylate and Its Copolymer}

3.2.1. IR Analysis of Tourmaline Acrylate. The IR spectra of unmodified tourmaline and modified tourmaline were shown in Figure 5. In Figure 5(a), unmodified tourmaline [14] has absorption bands at $3558 \mathrm{~cm}^{-1}$ (-OH group), $1272 \mathrm{~cm}^{-1}$ (B-O group), and $975 \mathrm{~cm}^{-1}$ ( $\mathrm{Si}-\mathrm{O}$ group), and the IR spectrum of modified tourmaline (Figure 5(b)) shows absorption bands of methyl $\left(2923 \mathrm{~cm}^{-1}\right)$, methylene $\left(2853 \mathrm{~cm}^{-1}\right)$, carbonyl $\left(1720 \mathrm{~cm}^{-1}\right)$, and double bond $\left(1630 \mathrm{~cm}^{-1}\right)$ of acryloyl group. After modification, the shape of absorption bands of tourmaline was almost unchanged, but the bands all showed red shift compared with that of the unmodified tourmaline owing to the electronic effect of acryloyl group. This indicated that acryloyl group has been introduced on the surface of tourmaline to produce the polymerizable tourmaline acrylate via the reaction of acryloyl chloride with tourmaline powder (Scheme 1).

3.2.2. The IR Spectra of Poly(methyl methacrylate-tourmaline acrylate). The IR spectra of poly(methyl methacrylatetourmaline acrylate) were shown in Figure 6. In Figure 6, besides the characteristic absorption peaks of poly(methyl methacrylate) at $3000 \mathrm{~cm}^{-1}$ and $2954 \mathrm{~cm}^{-1}\left(\mathrm{CH}_{3}\right.$ and $\left.\mathrm{CH}_{2}\right)$, $1731 \mathrm{~cm}^{-1}(\mathrm{C}=\mathrm{O}), 1485 \mathrm{~cm}^{-1}$ and $1447 \mathrm{~cm}^{-1}(\mathrm{C}-\mathrm{O})$, and $1190 \mathrm{~cm}^{-1}$ and $1151 \mathrm{~cm}^{-1}$ (C-O-C) [15], the absorption bands of tourmaline were found clearly at $3436 \mathrm{~cm}^{-1}$ (-OH group), $1273 \mathrm{~cm}^{-1}$ (B-O bands), and $986 \mathrm{~cm}^{-1}$ ( $\mathrm{Si}-\mathrm{O}$ bands) [14], 


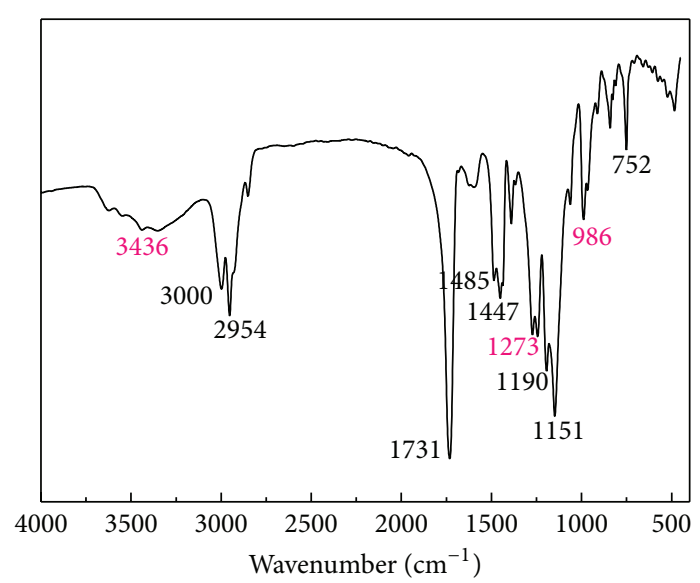

FIGURE 6: The IR spectrum of poly(methyl methacrylate-tourmaline acrylate).

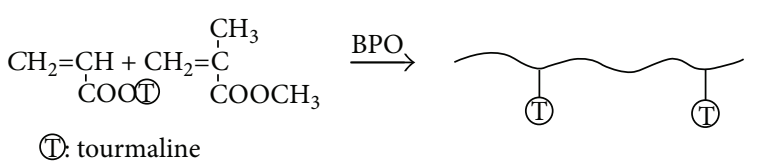

SCHEME 2

which correspond to those of poly(methyl methacrylatetourmaline acrylate). This demonstrated that tourmaline was successfully introduced into copolymer by copolymerization of tourmaline acrylate with methyl methacrylate (Scheme 2).

3.2.3. Stabilization of Copolymer. Figure 7 shows the storage stability of copolymers. The poly(methyl methacrylate-tourmaline acrylate) displayed excellent stability (Figure 7(b)) after storage for 30 days. There is no sedimentation of tourmaline observed, and only a little solvent separated out in the top layer due to the dissolubility of copolymer in the process of longtime storage. In contrast, obvious tourmaline sediment appeared in less than a week for the poly(methyl methacrylate-tourmaline) obtained by the same procedure (Figure 7(a)). These observations also indicated that tourmaline was introduced into the copolymer to be poly(methyl methacrylate-tourmaline acrylate) via the preparation of tourmaline acrylate and copolymerization.

3.2.4. X-Ray Fluorescence (XRF) Analysis of Copolymer. In order to confirm the existence of tourmaline in copolymer, the XRF analysis was shown in Table 1 . The results indicated that $\mathrm{Si}, \mathrm{Al}, \mathrm{Na}, \mathrm{Mg}, \mathrm{Fe}, \mathrm{Ca}$, and other elements were detected in copolymer, which is in accordance with the characteristic of tourmaline [14]. So the tourmaline was suitable to be incorporated into copolymer to get tourmaline-containing copolymer.

3.3. SEM Images of Tourmaline-Containing Fibers. Figures $8(\mathrm{a})$ and $8(\mathrm{~b})$ show the SEM images of electrospinning fibers of poly(methyl methacrylate-tourmaline acrylate) and poly(methyl methacrylate-tourmaline), respectively.

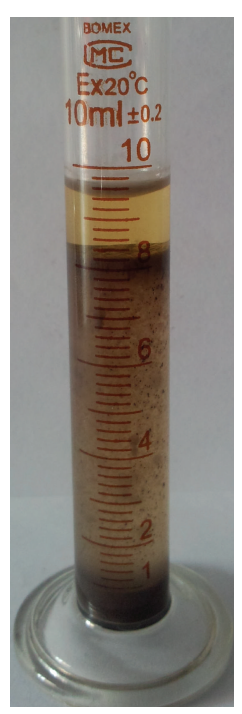

(a)

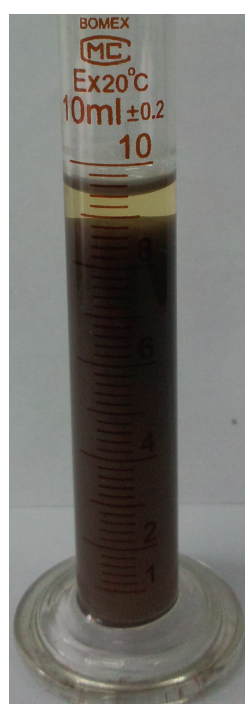

(b)
FIGURE 7: The storage stability of copolymer.

TABLE 1: The X-ray fluorescence analysis of copolymer.

\begin{tabular}{lc}
\hline Components & Mass percent (\%) \\
\hline $\mathrm{SiO}_{2}$ & 1.88 \\
$\mathrm{Al}_{2} \mathrm{O}_{3}$ & 0.431 \\
$\mathrm{Na}_{2} \mathrm{O}$ & 0.399 \\
$\mathrm{MgO}$ & 0.297 \\
$\mathrm{Fe}_{2} \mathrm{O}_{3}$ & 0.295 \\
$\mathrm{CaO}$ & 0.158 \\
$\mathrm{TiO}_{2}$ & 0.005 \\
$\mathrm{MnO}_{2}$ & 0.0036 \\
$\mathrm{~K}_{2} \mathrm{O}$ & 0.0359 \\
\hline
\end{tabular}

TABLE 2: The amount of negative ions released.

\begin{tabular}{lc}
\hline Sample & The amount of negative ions $\left(\right.$ ions $\left./ \mathrm{cm}^{3}\right)$ \\
\hline Tourmaline & 300 \\
Modified tourmaline & 500 \\
Copolymer & 400 \\
\hline
\end{tabular}

Figure 8(a) indicated that the particle size of tourmaline was much smaller and well-distributed in copolymer, while tourmaline showed agglomeration obviously in poly (methyl methacrylate-tourmaline) (Figure 8(b)) and the fibers were brittle. This is because unmodified tourmaline could not be well dispersed and is easy to agglomerate, which would badly influence the performance of its composites. After modification with acryloyl chloride, the tourmaline was introduced evenly into copolymer by copolymerization to get tourmaline-containing copolymer with well distribution and good performance.

3.4. The Measurement of the Negative Ions. The amount of negative ions released from the tourmaline, modified tourmaline, and tourmaline-containing copolymer was listed in Table 2. From the data in Table 2, the amounts of released 


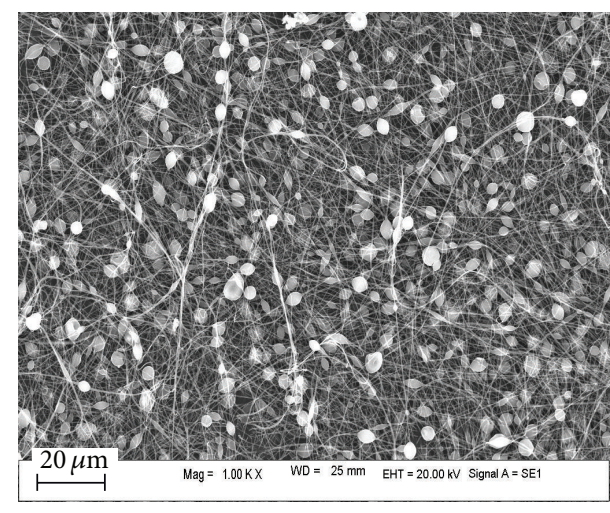

(a)

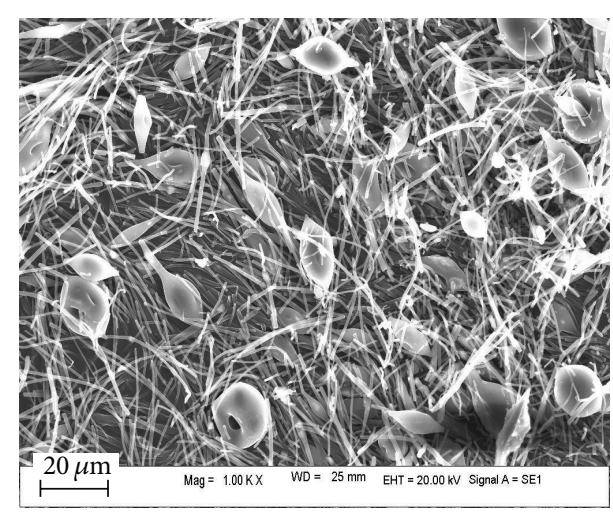

(b)

FIGURE 8: SEM images of electrospinning fibers of poly(methyl methacrylate-tourmaline acrylate) (a) and poly(methyl methacrylatetourmaline) (b).

negative ions of both modified tourmaline and tourmalinecontaining copolymer were greater obviously than that of tourmaline. This was because the surface energy and aggregation of the modified tourmaline particles were reduced, and the surface area of tourmaline particle increased, which resulted in an increased amount of released negative ions [11]. The negative ions amount from copolymer was a little lower than that from modified tourmaline because partial tourmaline was coated. But it is greater than that of tourmaline.

\section{Summary}

As a summary of this work, there are a few informative points: (1) the tourmaline was modified with acryloyl chloride to get polymerizable tourmaline acrylate; (2) the tourmalinecontaining poly(methyl methacrylate-tourmaline acrylate) was obtained by means of copolymerizing the tourmaline acrylate and methyl methacrylate; (3) the copolymer has an excellent storage stability; (4) the negative ions measurement indicated that the amount of released negative ions of both modified tourmaline and its copolymer is larger than that of unmodified tourmaline.

This work provided more extensive channels for development of novel functional materials and high-worth comprehensive utilization of tourmaline.

\section{Competing Interests}

The authors declare that they have no competing interests.

\section{Acknowledgments}

This work is supported by the National Natural Science Foundation of China (no. 51372233).

\section{References}

[1] L. Zhang, Y. Wu, and B. Xiao, "Research on the composition, structure and deep processing technology of tourmaline," Multipurpose Utilization of Mineral Resources, vol. 4, pp. 30-34, 2009.
[2] T. Kubo, "Interface activity of water given rise by tourmaline," Solid State Physics, vol. 24, pp. 1055-1060, 1989.

[3] J. Wei, Y. Y. Liu, and K. Y. Zhang, "Study on application features of tourmaline," Non-Metallic Mines, vol. 26, pp. 34-36, 2003.

[4] X. F. Zhang, R. H. Wu, and Y. Dong, "Research on surface electricity propriety of tourmaline powder," China Non-Metallic Minerals Industry, vol. 14, pp. 73-76, 2005.

[5] X. Yang, Y. M. Hu, and J. H. Zhu, "Surface modification and characterization of tourmaline powder by span 60," Multipurpose Utilization of Mineral Resources, vol. 1, pp. 14-17, 2011.

[6] D. J. Henry and M. K. de Brodtkorb, "Mineral chemistry and chemical zoning in tourmalines, Pampa del Tamboreo, San Luis, Argentina," Journal of South American Earth Sciences, vol. 28, no. 2, pp. 132-141, 2009.

[7] S.-J. Kang, L. D. Tijing, B.-S. Hwang, Z. Jiang, H. Y. Kim, and C. S. Kim, "Fabrication and photocatalytic activity of electrospun nylon- 6 nanofibers containing tourmaline and titanium dioxide nanoparticles," Ceramics International, vol. 39, no. 6, pp. 71437148, 2013.

[8] H.-Y. Xu, Z. Zheng, and G.-J. Mao, "Enhanced photocatalytic discoloration of acid fuchsine wastewater by $\mathrm{TiO}_{2} /$ schorl composite catalyst," Journal of Hazardous Materials, vol. 175, no. 1-3, pp. 658-665, 2010.

[9] L. D. Tijing, M.-H. Yu, C.-H. Kim et al., "Mitigation of scaling in heat exchangers by physical water treatment using zinc and tourmaline," Applied Thermal Engineering, vol. 31, no. 11-12, pp. 2025-2031, 2011.

[10] Z. F. Wu, H. Wang, M. Xue et al., "Facile preparation of superhydrophobic surfaces with enhanced releasing negative air ions by a simple spraying method," Composites Science and Technology, vol. 94, pp. 111-116, 2014.

[11] Y. M. Hu and X. Yang, "The surface organic modification of tourmaline powder by span-60 and its composite," Applied Surface Science, vol. 258, no. 19, pp. 7540-7545, 2012.

[12] L. D. Tijing, M. T. G. Ruelo, A. Amarjargal et al., "Antibacterial and superhydrophilic electrospun polyurethane nanocomposite fibers containing tourmaline nanoparticles," Chemical Engineering Journal, vol. 197, pp. 41-48, 2012.

[13] Y. Zheng and A. Q. Wang, "Removal of heavy metals using polyvinyl alcohol semi-IPN poly(acrylic acid)/tourmaline composite optimized with response surface methodology," Chemical Engineering Journal, vol. 162, no. 1, pp. 186-193, 2010. 
[14] P. S. R. Prasad and D. S. Sarma, "Study of structural disorder in natural tourmalines by infrared spectroscopy," Gondwana Research, vol. 8, no. 2, pp. 265-270, 2005.

[15] J. M. Zhang, X. G. Sun, and C. H. Wang, "Synthesis and kinetics study of $\mathrm{TiO}_{2} / \mathrm{P}$ (MMA-BA-MAA) composite particles by emulsion polymerization," CIESC Journal, vol. 60, no. 10, pp. 2640-2649, 2009. 

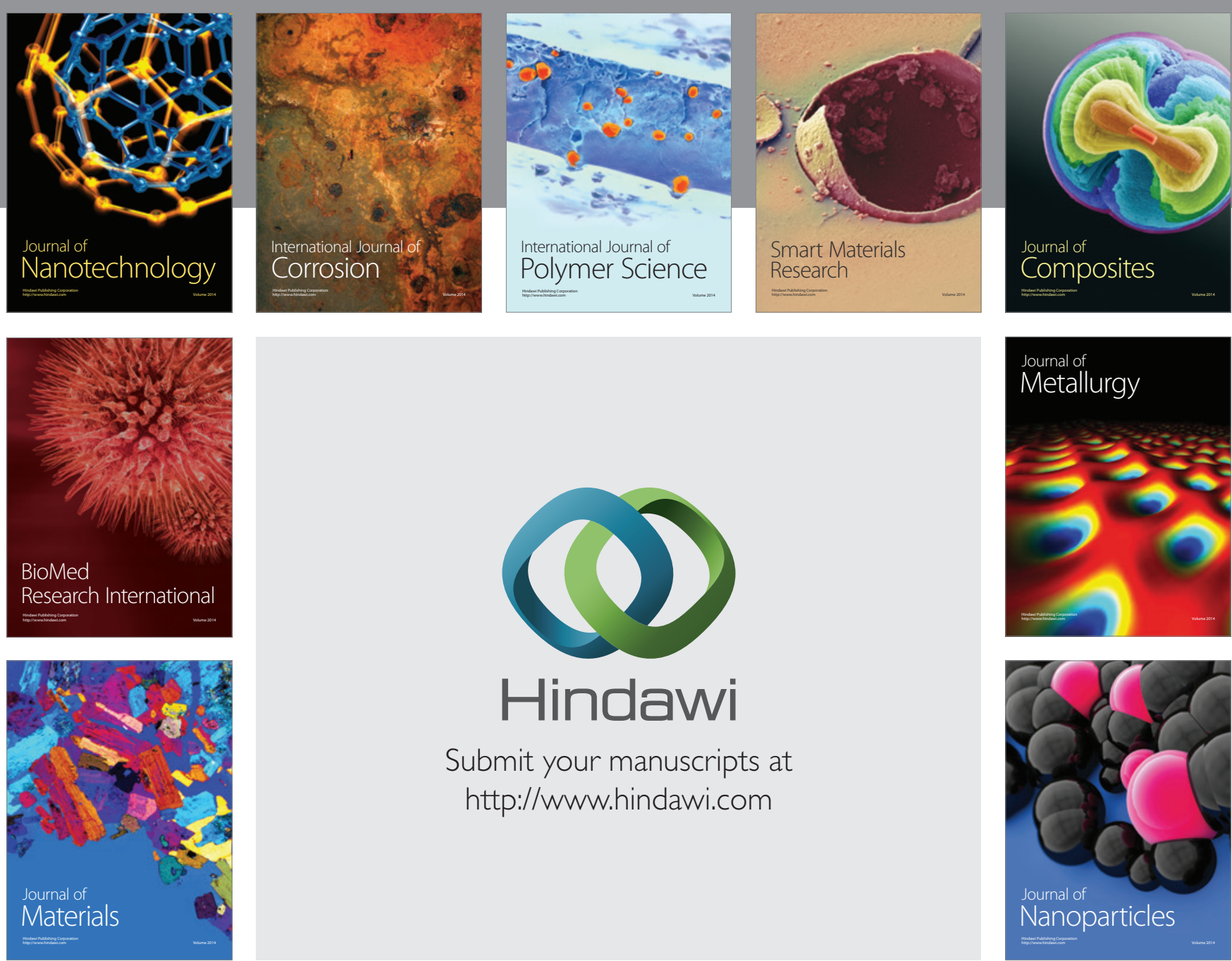

\section{Hindawi}

Submit your manuscripts at

http://www.hindawi.com

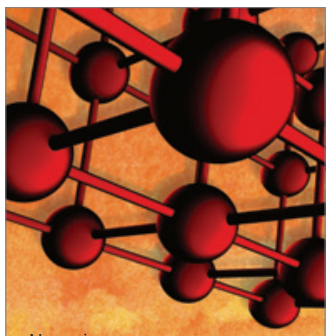

Materials Science and Engineering
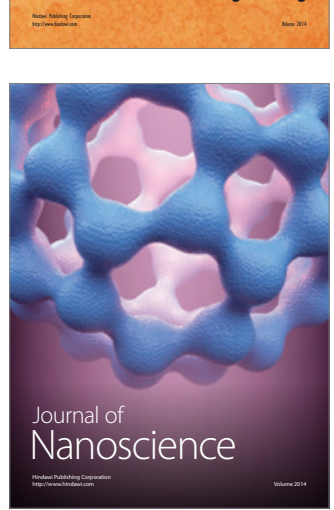
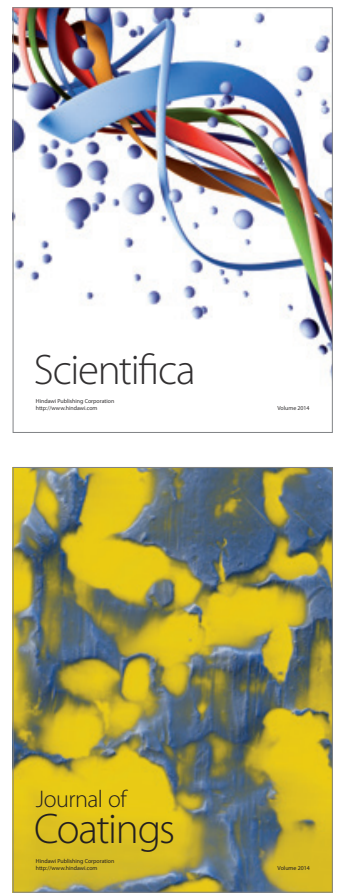
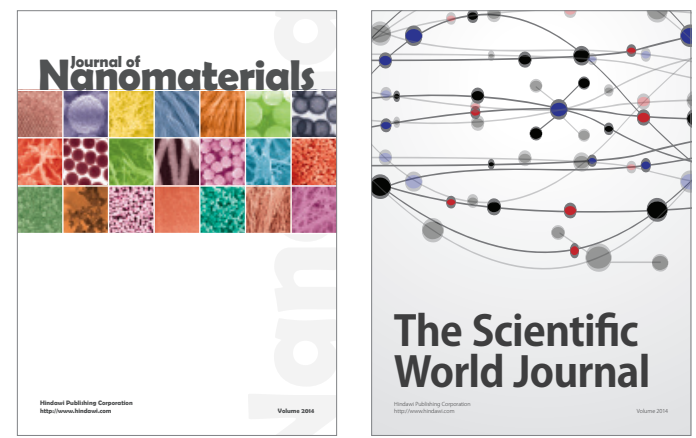

The Scientific World Journal
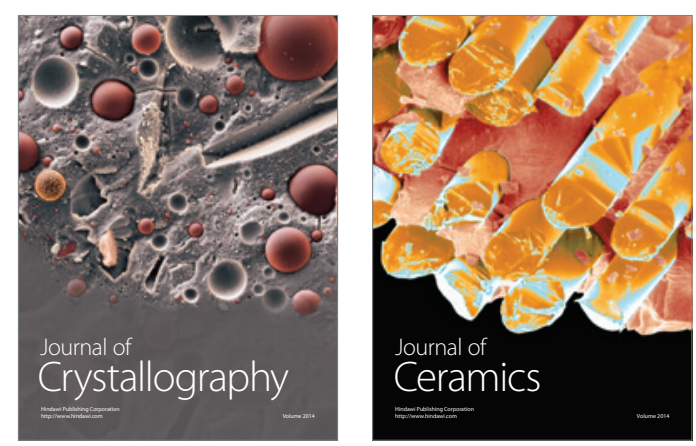
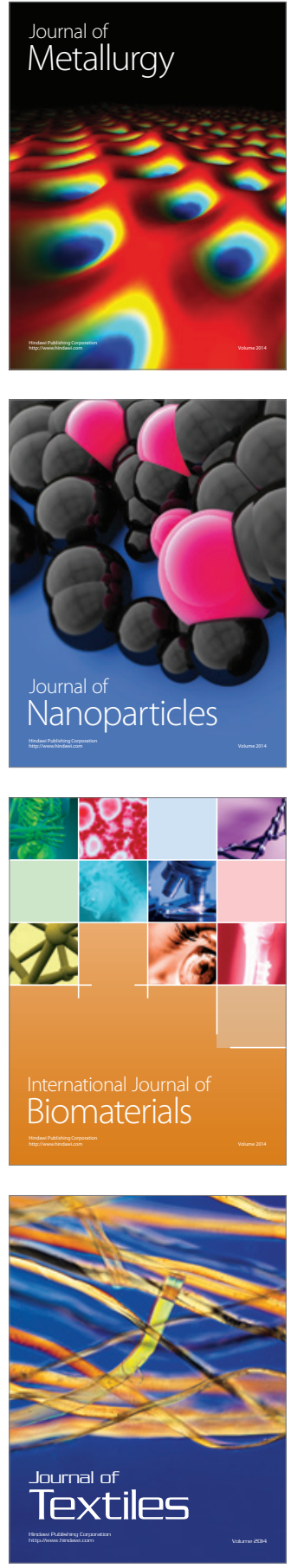